\title{
Problems and Countermeasures of Activity Design Teaching for Preschool Education Specialty in Higher Vocational College
}

\author{
ChenglinSuo ${ }^{1, *}$, ZelongLi ${ }^{2}$ \\ ${ }^{1}$ Anyang preschool education college, Anyang, Henan,456150, China \\ ${ }^{2}$ North China University of Technology, Beijing, 100043, China. \\ *Corresponding Author.
}

\begin{abstract}
There are some problems in the activity design teaching of preschool education in higher vocational education, such as teachers' professional quality needs to be improved, practical teaching is weak, teaching integration is weak, and students' learning autonomy is insufficient. These problems affect the improvement of students' ability and level of activity design. The main strategies of activity design teaching improvement are to build a contingent of high-quality teachers, strengthen practical teaching, improve the integration of teaching, and guide students to improve their autonomous learning level.
\end{abstract}

Keywords: Preschool education, activity design, teaching reform, practical teaching

\section{I.Introduction}

"Activity Design" refers to the design of educational activities for children aged 0-6 years, with emphasis on kindergarten educational activities. "Activity Design Teaching of pre-school Education Specialty" is a kind of teaching activity for teachers of higher vocational colleges to guide pre-school students to improve their activity design level. The planning and implementation of educational activities is the necessary professional ability of kindergarten teachers. Kindergarten teachers should have the ability to formulate periodic educational activity plans and specific educational activity plans. The design ability of preschool children's educational activities is the professional ability that students majoring in preschool education in higher vocational education must possess, and it is the foundation and premise of organizing and implementing preschool education activities.

\section{II.Problems of Activity Design Teaching for Preschool Education Specialty in Higher Vocational Education}

At present, many higher vocational colleges offer five teaching courses, such as preschool children's health education, preschool children's language, preschool children's social education, preschool children's science education and preschool children's art education. In recent years, the design and teaching activities of preschool education major in higher vocational colleges have been strengthened, and the level of student activity design has been improved. However, compared with the requirements of kindergarten education, there is still a certain gap in the level of student activity design, and there are obvious problems in activity design teaching.

\subsection{Teachers'professional quality}

Field education and activity design belong to the category of teaching method. It is an applied course which combines the theory of preschool education with the practice of preschool education and pays attention to the cultivation of students' educational ability[1].SIn order to do a good job in the teaching of activity design, teachers should have rich knowledge of educational theory and practical experience and ability of kindergarten education, which puts forward high requirements for teachers' professional quality.

From the teaching method teachers team, many higher vocational teachers have not been engaged in kindergarten education work, lack of practical experience and ability of kindergarten education; some teachers used to teach

ISSN: 0010-8189

(C) CONVERTER 2021

www.converter-magazine.info 
courses other than mathematics, physics, politics and other teaching methods, and later transferred to teaching methods, they also lack systematic theoretical knowledge of preschool education; because of the heavy teaching, scientific research tasks and imperfect evaluation system, many teachers lack the initiative to go deep into kindergarten first-line practice, lack the enthusiasm to become "double-qualified" teachers lack of teachers, subject leaders and other high-level talents are seriously inadequate. Compared with the teaching requirements of activity design, the professional quality of teachers is obviously insufficient. Teachers' professional quality affects the quality of activity design teaching: more one-way teaching of activity design teaching, less communication and interaction with students, less practical activities, and obviously insufficient effectiveness of practical guidance.

\subsection{Weakness in practice teaching}

Practical teaching is a combination of a series of teaching activities which are closely related to theoretical teaching. Under the guidance of teachers, students focus on practical operation, acquire perceptual knowledge and basic skills, and improve their comprehensive quality [2].Accumulating practical experience and improving practical ability is the only way to train high-quality preschool teachers [3].

At present, the practice teaching of preschool education in higher vocational education has not received due attention. The problems of theoretical knowledge," learning "and" using "are seriously disjointed, the practice course is insufficient, and the selection of practical training items and contents is not scientific, which leads to the mismatch between the quality of practical training and the goal of talent training [4].The syllabus (curriculum standard) of many higher vocational colleges shows that the total class hours of teaching courses in each field of kindergarten are generally $24 \sim 36$ hours, and the proportion of theoretical teaching to practical teaching is mostly $2: 1$ or 1 . In fact, many teaching courses account for more than half of the total class hours, and practical teaching time is obviously small. The activity design teaching emphasizes on the theory teaching, the practice teaching is relatively weak.

\subsection{Weak teaching integration}

Many teaching courses in higher vocational colleges belong to sub-subjects. There are many teaching hours, piecemeal and repetitive contents, and lack of overall planning of the whole teaching system[5].Activity design teaching covers the design and guidance of educational activities and comprehensive educational activities in five major fields of kindergarten, generally by a number of teaching teachers. At present, the main performance of the weak integration of activity design teaching is:(1) the repetition rate of curriculum content is high. The curriculum of teaching methods in the five major fields will arrange special chapters to explain the target system, educational methods, organizational forms, educational evaluation, activity design procedures and requirements of kindergarten educational activities. (2) Loose teaching activities. Teachers in all fields organize students to learn these common contents, resulting in repeated learning. Different teachers' teaching will also have contradictory or inconsistent content.

\subsection{Lack of autonomy in learning}

Students are the main body of learning, active planning, control and reflection of their own learning activities should be the state of students. However, due to the influence of current teaching methods and other factors, many students have insufficient learning autonomy[6].The main performance is:(1) Self-learning consciousness is weak. At present, many preschool normal students have weak consciousness of independent development and do not attach importance to the study of teaching methods and other related courses[7].(2) Autonomous learning ability is not strong. On the whole, the overall level of autonomous learning ability of students majoring in preschool education in higher vocational education, including autonomous learning motivation and autonomous learning strategies, has just reached the middle level, and there is still a lot of room for improvement in autonomous learning ability. The overall level needs to be improved (see table 1)[8].In the teaching of activity design, the majority of students are able to make reasonable study plans and implement them conscientiously. Many students'theoretical study is not serious, theoretical knowledge is difficult to transfer to practical activities; when 
learning difficulties, many students are not good at independent thinking and independent inquiry, plagiarism of other people's program of activities is more common.

Table1 Statistical description of the total status quo of autonomous learning ability of students majoring in pre-school education in higher vocational education

\begin{tabular}{|c|c|c|c|}
\hline & total people(N) & M & SD \\
\hline Learning Motivation Subscale & 260 & 126.56 & 12.170 \\
\hline Learning Strategy Subscale & 260 & 164.20 & 15.964 \\
\hline Overall level of self-learning ability & 260 & 290.76 & 26.017 \\
\hline
\end{tabular}

Because of the above problems, it affects the development of students' activity design ability and level. After half a semester of activity design study, a sample survey was carried out on the students of the three-year system of preschool education major in grade 2018. The results of the questionnaire survey and interview (see Table 2) show that the students have a good grasp of the structure of the activity plan, the arrangement of the activity content, and the gradual progress of the activity process. However, there are still obvious deficiencies in the orientation of the key points and difficulties of the activities, the grasp of the performance level of children of different ages, and the design of specific and clear goals.

Table 2 Summary of student activity design surveys for pre-school students

\begin{tabular}{|c|c|c|c|c|c|}
\hline Project & $\begin{array}{c}\text { Very } \\
\text { consistent } \\
(\%)\end{array}$ & $\begin{array}{c}\text { Comparativeconformity } \\
(\%)\end{array}$ & $\begin{array}{c}\text { General } \\
(\%)\end{array}$ & Comparativenon-conformity(\%) & $\begin{array}{c}\text { Very } \\
\text { inconsistent } \\
(\%)\end{array}$ \\
\hline $\begin{array}{l}\text { Complete } \\
\text { description of } \\
\text { the structure of } \\
\text { the programme } \\
\text { of activities }\end{array}$ & 40 & 34 & 26 & 0 & 0 \\
\hline $\begin{array}{l}\text { Can accurately } \\
\text { grasp the } \\
\text { existing ability } \\
\text { of young } \\
\text { children }\end{array}$ & 9 & 51 & 38 & 2 & 0 \\
\hline $\begin{array}{l}\text { Can accurately } \\
\text { grasp the } \\
\text { performance } \\
\text { level of } \\
\text { children of } \\
\text { different ages } \\
\text { in the Guide }\end{array}$ & 2 & 32 & 49 & 17 & 2 \\
\hline $\begin{array}{c}\text { Be able to } \\
\text { design specific } \\
\text { and clear goals }\end{array}$ & 11 & 36 & 42 & 11 & 0 \\
\hline $\begin{array}{l}\text { Be able to } \\
\text { design } \\
\text { appropriate } \\
\text { activity } \\
\text { priorities and } \\
\text { difficulties }\end{array}$ & 8 & 27 & 32 & 25 & 8 \\
\hline $\begin{array}{c}\text { Selection of } \\
\text { appropriate } \\
\text { activity content }\end{array}$ & 19 & 68 & 13 & 0 & 0 \\
\hline $\begin{array}{l}\text { Flexible choice } \\
\text { of different } \\
\text { organizational } \\
\text { forms }\end{array}$ & 6 & 26 & 60 & 8 & 0 \\
\hline
\end{tabular}

ISSN: 0010-8189 


\begin{tabular}{|c|c|c|c|c|c|}
\hline $\begin{array}{c}\text { The activity } \\
\text { link achieves } \\
\text { the step by step }\end{array}$ & 9 & 53 & 38 & 0 & 0 \\
\hline
\end{tabular}

A comparative study of 140 students in the experimental class of pre-school program of excellence was carried out. It was found that before and after the first semester of junior year, there were inefficient difficulties in the design of collective teaching activities in the aspects of goal expression, emphasis and difficulty orientation, process design and so on (see tables 3,4 and 5).

Table 3 Statistics of students' ability to design "activity objectives" before and after learning the guide of integration of kindergarten activities

\begin{tabular}{|c|c|c|c|c|c|}
\hline $\begin{array}{c}\text { Observation } \\
\text { point }\end{array}$ & Problems & $\begin{array}{c}\text { Number of } \\
\text { students before } \\
\text { study }\end{array}$ & $\begin{array}{c}\text { The } \\
\text { proportion }\end{array}$ & $\begin{array}{c}\text { Numberof } \\
\text { students after } \\
\text { study }\end{array}$ & $\begin{array}{c}\text { The } \\
\text { proportion }\end{array}$ \\
\hline \multirow{3}{*}{$\begin{array}{c}\text { Moving } \\
\text { target }\end{array}$} & $\begin{array}{c}\text { The subject of objectiveexpression is not } \\
\text { unified }\end{array}$ & 101 & 72 & 16 & 11 \\
\cline { 2 - 6 } & $\begin{array}{c}\text { The objective statement is incomplete } \\
\text { pertinence and operate }\end{array}$ & 86 & 61 & 18 & 13 \\
\cline { 2 - 6 } & $\begin{array}{c}\text { The objective statement deviates from the } \\
\text { field requirements of the Guidelines and } \\
\text { the Outline }\end{array}$ & 103 & 72 & 36 & 26 \\
\hline
\end{tabular}

Table 4 Statistics of students' ability to design "key and difficult points" before and after learning the guide of integration of kindergarten activities

\begin{tabular}{|c|c|c|c|c|c|}
\hline $\begin{array}{c}\text { Observatio } \\
\text { n point }\end{array}$ & Existing problems & $\begin{array}{c}\text { Number of students } \\
\text { before study } \\
\text { (unit:person time) }\end{array}$ & $\begin{array}{c}\text { Proportion } \\
\text { (\%) }\end{array}$ & $\begin{array}{c}\text { Number of } \\
\text { students after study } \\
\text { (unit:person time) }\end{array}$ & $\begin{array}{c}\text { Proportio } \\
\mathrm{n}(\%)\end{array}$ \\
\hline \multirow{2}{*}{$\begin{array}{c}\text { Key points and } \\
\text { difficulties of } \\
\text { activities }\end{array}$} & $\begin{array}{c}\text { The focus and difficulty of the activity } \\
\text { are confused with the goal }\end{array}$ & 126 & 90 & 38 & 27 \\
\cline { 2 - 6 } & $\begin{array}{c}\text { The focus of activities can not be } \\
\text { effectively defined }\end{array}$ & 130 & 93 & 39 & 28 \\
\hline
\end{tabular}

Table 5 Statistics of Students' ability to design "Activity process" before and after learning the guide of integration of kindergarten activities

\begin{tabular}{|c|c|c|c|c|c|}
\hline $\begin{array}{c}\text { Observation } \\
\text { point }\end{array}$ & Existing problems & $\begin{array}{c}\text { Number of students } \\
\text { before study }\end{array}$ & $\begin{array}{c}\text { Proportion } \\
(\%)\end{array}$ & $\begin{array}{c}\text { Number of students } \\
\text { after study }\end{array}$ & Proportion (\%) \\
\hline \multirow{5}{*}{$\begin{array}{c}\text { The activity process is } \\
\text { not complete, there is no } \\
\text { beginning and no end }\end{array}$} & 78 & 56 & 11 & 8 \\
\cline { 2 - 6 } $\begin{array}{c}\text { There is no logical } \\
\text { Process } \\
\text { links in the activity } \\
\text { process }\end{array}$ & $\begin{array}{c}\text { The language expression } \\
\text { of activity process is } \\
\text { cumbersome and not } \\
\text { refined }\end{array}$ & 96 & 69 & 13 & 9 \\
\cline { 2 - 6 } & $\begin{array}{c}\text { Use "Teacher:..." } \\
\text { "Young:..." formulation }\end{array}$ & 106 & 76 & 18 & 13 \\
\cline { 2 - 6 } & $\begin{array}{c}\text { The expression of } \\
\text { activity process does not } \\
\text { highlight the teaching }\end{array}$ & 98 & 70 & 26 & 19 \\
\hline
\end{tabular}

ISSN: 0010-8189 


\begin{tabular}{|c|c|c|c|c|}
\hline method & & & & \\
\hline $\begin{array}{l}\text { The activity import task } \\
\text { is not clear }\end{array}$ & 118 & 84 & 32 & 24 \\
\hline $\begin{array}{l}\text { The main goal and } \\
\text { emphasis of the activity } \\
\text { are put into the activity } \\
\text { introduction }\end{array}$ & 65 & 8 & 16 & 11 \\
\hline $\begin{array}{l}\text { The arrangement of the } \\
\text { three parts of the } \\
\text { activity process is } \\
\text { unreasonable }\end{array}$ & 98 & 70 & 6 & 4 \\
\hline $\begin{array}{l}\text { Do not understand the } \\
\text { core task of the end of } \\
\text { the activity, the end of } \\
\text { the activity perfunctory }\end{array}$ & 89 & 64 & 12 & 9 \\
\hline $\begin{array}{l}\text { The end of the activity } \\
\text { is designed as an } \\
\text { extension of the activity }\end{array}$ & 126 & 90 & 16 & 11 \\
\hline $\begin{array}{l}\text { The activity process is } \\
\text { not related to the } \\
\text { activity goal }\end{array}$ & 122 & 87 & 2 & 1 \\
\hline
\end{tabular}

III.Strategies for Improving Teaching of Activity Design for Preschool Education Specialty in Higher Vocational Education

In view of the problems existing in the teaching of activity design, higher vocational schools need to adjust and improve in the following four aspects.

\subsection{Building a contingent of highly qualified teachers}

Only high-quality "double-qualified" teachers can better combine professional theory with practice, achieve the "integration of theory and practice" of teaching, and cultivate high-quality applied talents[9].Activity design has the characteristics of comprehensiveness and creativity, and the teaching of activity design urgently needs high-quality "double-qualified" teachers who can be competent in theory teaching and practice teaching[10].

\subsubsection{Do a good job in teacher introduction and management}

According to the needs of teaching methods such as activity design, the school should seriously analyze the present situation of teaching teachers, make a good plan for the construction of high-quality "double-qualified" teachers, strengthen the construction of teachers through various channels, and promote the improvement of teachers' professional quality. Schools should formulate policies or systems for the introduction of high-level talents, introduce high-level talents such as professors and academic leaders to teach or serve as part-time professors; employ kindergarten directors, teachers and teaching and research staff with strong practical ability and good theoretical basis as part-time teachers or practical guidance teachers of teaching methods, arrange for them to do a good job in guiding the practical activities of young teachers and students, and give corresponding treatment according to their working conditions.

\subsubsection{Improving incentives for professional development of teachers}

Schools should establish and improve the incentive mechanism for teachers' professional development[11].To establish more appropriate standards for assessment of work, and to make in-depth practice, professional ability upgrading, practical teaching level and social service ability an important part of teachers' daily assessment to gradually establish and improve the management system of "double-qualified" teachers and clarify the contents of "double-qualified" teachers' job evaluation, welfare treatment, selection and appointment, and training promotion; 
and to adjust and improve the relevant systems to give priority to the needs of "double-qualified" teachers in job evaluation and recruitment.

\subsubsection{Training of teachers}

Schools should strengthen teacher training through various channels to promote the improvement of teachers' professional quality.Through organizing teachers to go deep into kindergarten to listen to classes and participate in activities, we can guide teachers to enrich the practical experience of kindergarten education in a planned and organized way, and improve their ability of educational practice. Guide teachers to master systematic educational theory knowledge and improve professional quality. Establish a "double tutors system" to train young teachers[12].

\subsection{Strengthening practical teaching}

Practical activities are of great significance to the professional development of teachers. The structure of teachers' professional quality is increasingly showing practical orientation. Curriculum teaching should strengthen practical links and practical teaching[13]. The activity design teaching should strengthen the practice teaching, highlight the student activity design ability development.

\subsubsection{Practice orientation of strengthening teaching}

Theoretical teaching and practical teaching are two inseparable parts of the teaching system. Practical teaching is based on theoretical teaching and should be carried out under the guidance of professional theory. To cultivate students' practical ability to serve[14].Practice teaching should be the focus of higher vocational teaching, the proportion of class hours should be more than $50 \%$. On the basis of a large number of studies, the evaluation scale of students' activity design ability of preschool education major in higher vocational education is developed (see Table 6), which provides support for the evaluation of students' activity design ability.

Table 6 Evaluation scale of students' activity design ability in preschool education

\begin{tabular}{|c|c|c|c|c|c|c|}
\hline \multirow[b]{2}{*}{$\begin{array}{l}\text { Levelindicator } \\
\qquad \mathrm{S}\end{array}$} & \multirow[b]{2}{*}{$\begin{array}{l}\text { Secondary } \\
\text { indicators }\end{array}$} & \multicolumn{5}{|c|}{ Rating (rating) } \\
\hline & & $\begin{array}{c}\text { Very } \\
\text { consisten } \\
\mathrm{t} \\
\text { (5 points) }\end{array}$ & $\begin{array}{c}\text { Compariso } \\
\mathrm{n} \\
\text { (4points) }\end{array}$ & $\begin{array}{l}\text { General } \\
\text { (3points } \\
\text { ) }\end{array}$ & $\begin{array}{l}\text { Comparativenon-conformit } \\
\text { y } \\
(2 \text { points })\end{array}$ & $\begin{array}{l}\text { Very } \\
\text { inconsisten } \\
\mathrm{t}(1)\end{array}$ \\
\hline \multirow{5}{*}{ Scientific } & $\begin{array}{c}\text { Can } \\
\text { accurately } \\
\text { grasp the } \\
\text { existing level } \\
\text { of experience } \\
\text { of young } \\
\text { children }\end{array}$ & & & & & \\
\hline & $\begin{array}{l}\text { Pay attention } \\
\text { to the main } \\
\text { position of } \\
\text { children }\end{array}$ & & & & & \\
\hline & $\begin{array}{c}\text { Correct } \\
\text { content of } \\
\text { activities } \\
\end{array}$ & & & & & \\
\hline & $\begin{array}{c}\text { Systematic } \\
\text { content of } \\
\text { activities } \\
\text { reflecting } \\
\text { knowledge } \\
\text { and } \\
\text { experience }\end{array}$ & & & & & \\
\hline & $\begin{array}{c}\text { Activity } \\
\text { processes }\end{array}$ & & & & & \\
\hline
\end{tabular}

ISSN: 0010-8189 


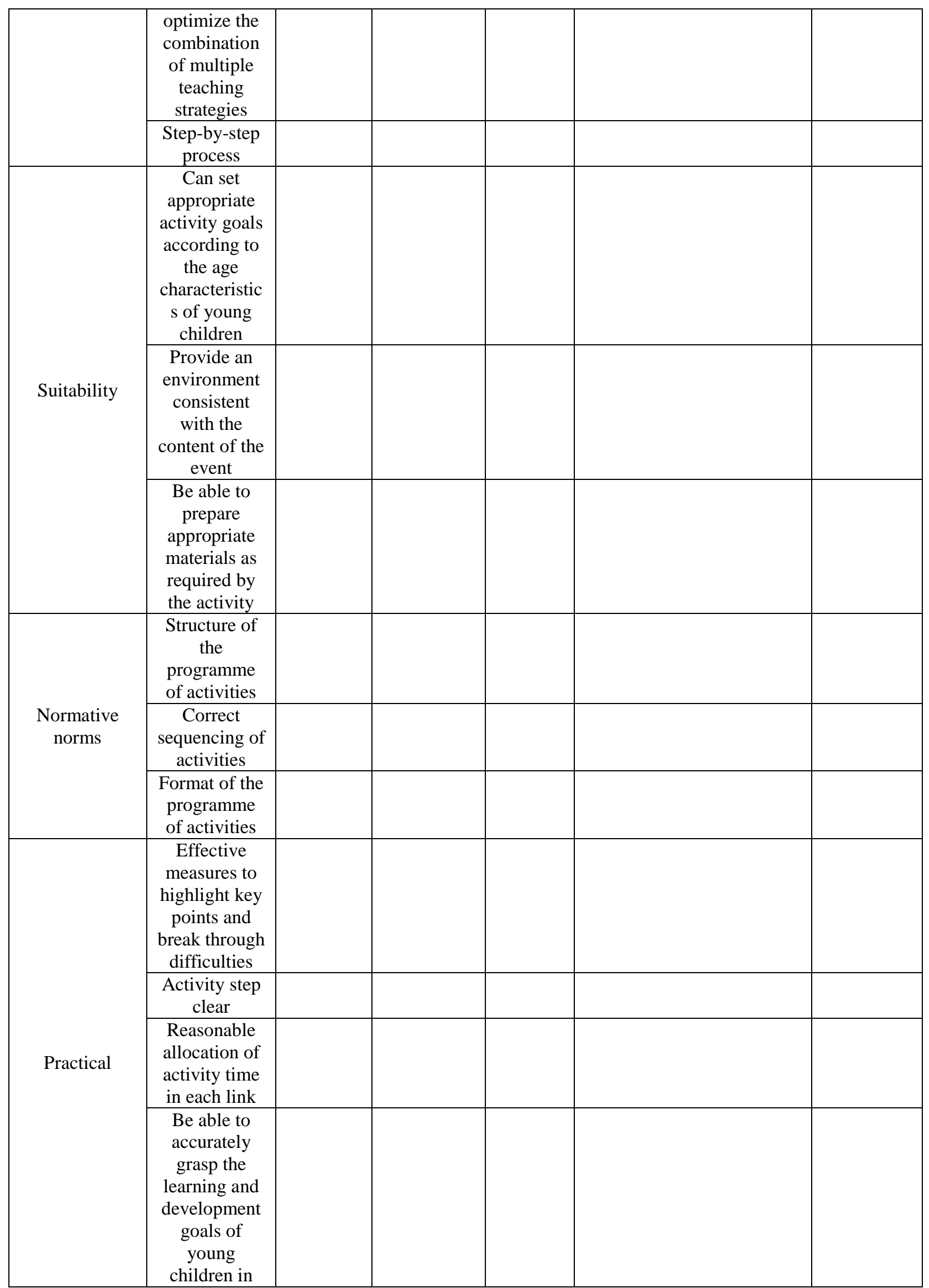




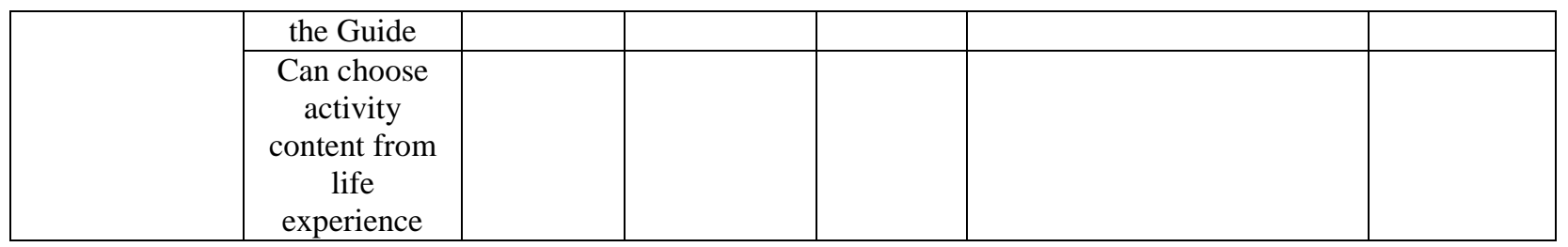

3.2.2. Rational organization of practical activities in schools

In this mode, the process of student activity plan design can be summarized as the following steps (see figure 1)[15].

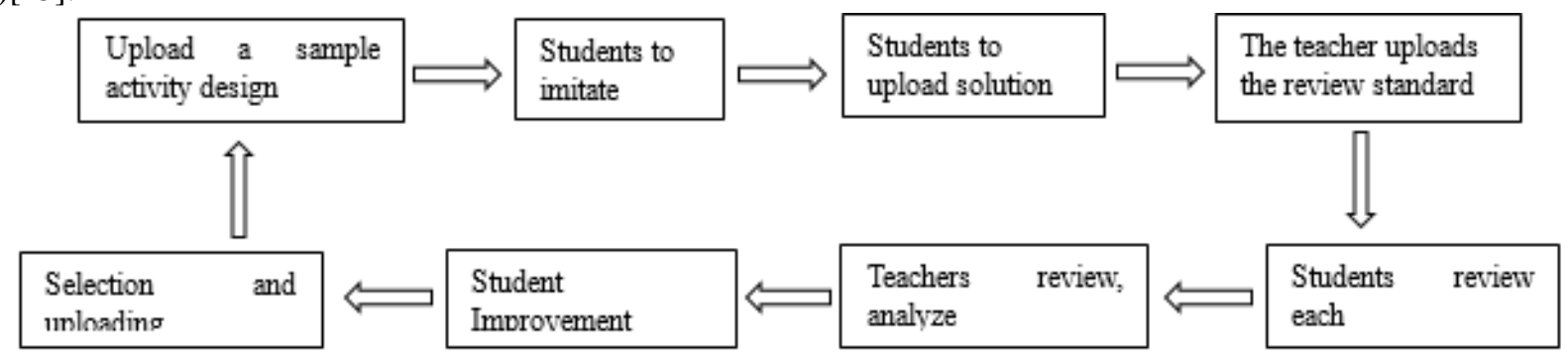

Fig 1: Design of Student Activity Scheme

3.2.3. Rational organization of off-campus practical activities

Kindergarten practice and other practical activities have an important impact on the development of students' activity design ability and level. In the outside practice activities such as kindergarten probation, educational practice and post practice, students can contact and communicate directly with young children, which is helpful to enhance their understanding of the development level of children in various age classes, and to set the goal of activities reasonably. The time of practice activities outside school should be arranged reasonably, which should be closely related to the design and teaching of activities and promote each other. Outside school practice activities should be arranged in provincial demonstration, municipal level and other high-level kindergartens. Students' practical activities outside school need effective guidance. It is necessary to establish a "double tutor system" for students' practical activities, guide students' practical activities outside school, and promote students' growth and development.

\subsection{Iimproving the integration of teaching}

Improving the integration of teaching is helpful to connect the scattered teaching objectives, contents and methods, realize the sharing of resources and work together, form a valuable and efficient whole, strengthen the educational resultant force, and improve the level and quality of activity design teaching. The teaching curriculum of preschool education should embody comprehensive education and abandon the teaching mode of separate and separate[16].

\subsubsection{Strengthening the integration of curriculum content}

Through the revision of the training program for preschool education professionals and the syllabus (curriculum standards) of teaching methods, the interrelation and mutual support between the courses are strengthened. The content of teaching method is integrated into "basic theory of kindergarten education activity — design and implementation of kindergarten education activity — design and guidance of kindergarten comprehensive activity "(see Table 7). Reduce duplication and inconsistency of content and enhance the interconnection and support of course content.

ISSN: 0010-8189 
Table 7 Content system of teaching method for pre-school students in higher vocational education

\begin{tabular}{|c|c|c|c|c|c|}
\hline Level1 content & Level 2 content & $\begin{array}{l}\text { Opening of } \\
\text { semester }\end{array}$ & $\begin{array}{l}\text { Hours } \\
\text { of } \\
\text { study }\end{array}$ & $\begin{array}{l}\text { Theoretical } \\
\text { hours }\end{array}$ & $\begin{array}{l}\text { Practical } \\
\text { hours }\end{array}$ \\
\hline \multirow{6}{*}{$\begin{array}{l}\text { Basic Theory of Kindergarten } \\
\text { Educational Activities }\end{array}$} & $\begin{array}{l}\text { Overview of kindergarten } \\
\text { education activities }\end{array}$ & $\begin{array}{c}\text { Third } \\
\text { semester }\end{array}$ & 2 & 2 & 0 \\
\hline & $\begin{array}{c}\text { Objectives and content of } \\
\text { kindergarten education } \\
\text { activities }\end{array}$ & $\begin{array}{l}\text { Third } \\
\text { semester }\end{array}$ & 2 & 1 & 1 \\
\hline & $\begin{array}{l}\text { Methods and forms of } \\
\text { kindergarten education } \\
\text { activities }\end{array}$ & $\begin{array}{l}\text { Third } \\
\text { semester }\end{array}$ & 2 & 1 & 1 \\
\hline & $\begin{array}{c}\text { Preparation of a programme } \\
\text { of kindergarten education } \\
\text { activities }\end{array}$ & $\begin{array}{l}\text { Third } \\
\text { semester }\end{array}$ & 2 & 1 & 1 \\
\hline & $\begin{array}{c}\text { Implementation of } \\
\text { kindergarten education } \\
\text { activities }\end{array}$ & $\begin{array}{c}\text { Fourth } \\
\text { semester }\end{array}$ & 2 & 1 & 1 \\
\hline & $\begin{array}{c}\text { Evaluation of kindergarten } \\
\text { education activities }\end{array}$ & $\begin{array}{c}\text { Third } \\
\text { semester }\end{array}$ & 2 & 1 & 1 \\
\hline \multirow{5}{*}{$\begin{array}{l}\text { Design and Implementation of } \\
\text { Educational Activities in Five } \\
\text { Areas of Kindergarten }\end{array}$} & $\begin{array}{l}\text { Kindergarten Health } \\
\text { Education Activities }\end{array}$ & $\begin{array}{c}\text { Third } \\
\text { semester }\end{array}$ & 32 & 16 & 16 \\
\hline & $\begin{array}{c}\text { Language education } \\
\text { activities in kindergartens }\end{array}$ & $\begin{array}{c}\text { Fourth } \\
\text { semester }\end{array}$ & 32 & 16 & 16 \\
\hline & $\begin{array}{l}\text { Kindergarten Social } \\
\text { Education Activities } \\
\end{array}$ & $\begin{array}{c}\text { Third } \\
\text { semester }\end{array}$ & 32 & 16 & 16 \\
\hline & $\begin{array}{c}\text { Kindergarten Scientific } \\
\text { Education Activities }\end{array}$ & $\begin{array}{c}\text { Third } \\
\text { semester }\end{array}$ & 48 & 20 & 28 \\
\hline & $\begin{array}{c}\text { Kindergarten Arts Education } \\
\text { Activities }\end{array}$ & $\begin{array}{l}\text { Fourth } \\
\text { semester }\end{array}$ & 48 & 20 & 28 \\
\hline \multirow{2}{*}{$\begin{array}{c}\text { Design and Guidance of } \\
\text { Kindergarten Comprehensive } \\
\text { Education Activities }\end{array}$} & $\begin{array}{l}\text { Design and Guidance of } \\
\text { Kindergarten } \\
\text { Comprehensive Education } \\
\text { Activities }\end{array}$ & $\begin{array}{l}\text { Third } \\
\text { semester }\end{array}$ & 2 & 1 & 1 \\
\hline & $\begin{array}{c}\text { Design and Guidance of } \\
\text { Kindergarten Theme } \\
\text { Activities }\end{array}$ & $\begin{array}{l}\text { Third } \\
\text { semester }\end{array}$ & 4 & 2 & 2 \\
\hline \multicolumn{3}{|c|}{ Total } & 210 & 98 & 112 \\
\hline
\end{tabular}

3.3.2 Implement teaching on the basis of curriculum content integration

First of all, teachers of teaching methods should strengthen communication and cooperation, connect and support each other in teaching objectives, contents, methods and evaluation, embody the integration of teaching methods and courses, and better promote the development of students' professional ideas and teachers' ethics, professional knowledge and professional ability. Secondly, we should organize teaching teachers to discuss the integrated curriculum content and make clear the common or overlapping contents of teaching courses. Third, it is necessary to discuss the contradictory or inconsistent contents in the course of teaching methods, establish correct or reasonable contents, eliminate incorrect or unreasonable contents, unify ideological understanding, and reduce contradictions, conflicts or inconsistencies. Fourth, discuss the scientific and reasonable evaluation criteria of the activity plan (see Table 8), provide excellent activity plan cases, guide students to clarify the content and requirements of the activity design, and unify the format of the activity plan. Fifth, it is necessary to strengthen teaching inspection and supervision, enhance the standardization and coordination of teaching design in different courses and different teachers' activities, and reduce randomness and repeatability. 
Table 8 Evaluation criteria of student activity programme of pre-school major in higher vocational education

\begin{tabular}{|c|c|c|}
\hline Project & Evaluation content & Value \\
\hline Name of activity & $\begin{array}{l}\text { 1. indicate the area to which the activity belongs and the appropriate age class. } \\
\text { 2. writing standard. }\end{array}$ & 5 \\
\hline Activity objectives & $\begin{array}{l}\text { 1. the young child perspective } \\
\text { 2. goal covers the dimensions of cognition, ability and emotion; } \\
\text { 3. objectives are specific and feasible; } \\
\text { 4. goals are in line with the core goals of the field, in line with the age } \\
\text { characteristics of young children; } \\
\text { 5. embodies the spirit of the Guide to Kindergarten Education (trial) and the } \\
\text { Guide to Learning and Development for Children aged 3-6. }\end{array}$ & 15 \\
\hline $\begin{array}{l}\text { Activity focus and } \\
\text { difficulties }\end{array}$ & $\begin{array}{l}\text { 1. emphasis is on what young children need to focus on or improve } \\
\text { 2. difficulty is that children are difficult to master or improve the content }\end{array}$ & 10 \\
\hline Activity preparation & $\begin{array}{l}\text { 1. preparation should cover experience preparation, material preparation and } \\
\text { environmental preparation; } \\
\text { 2. environment layout, activity materials can effectively trigger and support } \\
\text { children's inquiry, communication, operation and so on. }\end{array}$ & 10 \\
\hline Activity process & $\begin{array}{l}\text { Each link of 1. activity revolves around the goal design, indicates each link design } \\
\text { goal; } \\
\text { 2. process arrangement level is clear, step by step, accord with the child cognition } \\
\text { law; } \\
\text { 3. the activity time arrangement is reasonable, highlights the key point, breaks } \\
\text { through the difficult time to be sufficient; } \\
\text { 4. to play as the basic form of activities, appropriate use of a variety of teaching } \\
\text { methods and means; } \\
\text { 5. flexible use of collective, group and regional forms of teaching organization; } \\
\text { 6. question design is enlightening; } \\
\text { 7. activity design has new ideas. }\end{array}$ & 40 \\
\hline Activity extension & $\begin{array}{l}\text { 1. use objective description } \\
\text { 2. around the goal of activities, expand rich; } \\
\text { 3. extension is reasonable and feasible. }\end{array}$ & 10 \\
\hline Format and other & $\begin{array}{l}\text { 1. subheadings and the first line of each paragraph } \\
\text { 2. Serial Code } \\
\text { 3. writing standard, clear handwriting } \\
\text { 4.600-900 words. }\end{array}$ & 10 \\
\hline
\end{tabular}

3.4Guide students to improve their autonomous learning

The teaching task of teachers is not only to promote the development of students' knowledge, skills and values, but also to promote students to become autonomous learners and finally to become social citizens with good lifelong learning ability[17].In the teaching of activity design, teachers should deeply understand the significance and value of autonomous learning for students' development, improve teaching methods and guide students to improve their autonomous learning level.

\subsubsection{Guiding students to enhance their awareness of autonomous learning}

Under the influence of many factors, many students are used to following the teaching mode of teachers' learning, and form the corresponding thinking and behavior. The deep promotion of teachers to students' autonomous learning is to help students establish a sense of value and meaning of autonomous learning, to make students realize the importance of autonomous learning, to identify with autonomous learning behavior, and to take autonomous learning as the basic path to realize their own value. Thus autonomous learning becomes an individual necessity[18].Teachers should guide students to fully understand and identify with the significance and value of autonomous learning, enhance their awareness of autonomous learning, guide students to feel and experience the 
significance and value of autonomous learning in their learning activities, and strengthen their recognition and adherence to autonomous learning.

\subsubsection{Guide students to learn independently}

In the teaching of activity design, teachers should reform the teaching method centered on teachers, respect the main position of students, encourage students to express boldly, and actively explore the teaching method centered on students' learning. Fully understand each student's learning level and characteristics, arrange difficult levels, complete the learning tasks that require different learning tasks, guide students to choose learning tasks that match their own learning abilityguide students to formulate reasonable autonomous learning plans, strengthen autonomous, cooperative and inquiry learning, strengthen reflection and regulation of learning activities, guide students to learn to observe and think, improve their ability to analyze and solve problems, and gradually form good autonomous learning abilities and habits[19].

\section{IV.Conclusions}

The corresponding teaching reform is carried out in view of the problems existing in the teaching of activity design. In order to test the effect of the activity design teaching reform, The final examination results of activity design of 2017 and 2018 students in Anyang Teachers College were compared and analyzed. Each grade selects two more close classes (92 in 2017, A total of 100 people were selected in class 2018, Enter their final activity design test scores into the spss23.0 statistics, A t test of two grade specimens, A significant difference $(\mathrm{t}=-7.831$, $\mathrm{p}=0.000<0.05)$, Grade 2018(M=87.722, $\mathrm{SD}=3.986$ was significantly higher $(\mathrm{MSD}=81.700, \mathrm{SD}=5.515)(\mathrm{see}$ table 9).

Table 9 Grade 2017 and grade 2018 final activity design examination results analysis

\begin{tabular}{|c|c|c|c|c|c|}
\hline & $\mathrm{N}$ & $\mathrm{M}$ & $\mathrm{SD}$ & $\mathrm{t}$ & $\mathrm{P}$ \\
\hline Level 2017 & 92 & 81.700 & 5.515 & \multirow{2}{*}{-7.831} & \multirow{2}{*}{$0.000^{* *}$} \\
\hline Grade 2018 & 100 & 87.722 & 3.986 & & \\
\hline
\end{tabular}

Note:* $\mathrm{P}<0.01$.

The text analysis of the activity plan of the students in the two grades shows that the activity design of the students in grade 17 and grade 18 has shortcomings, but they both have the basic ability of activity design. On the whole, the students of grade 18 are obviously superior to the students of grade 17 in the consistency of activity process and goal, the degree of consistency between activity process and title requirement, the setting of activity goal, and the level of activity design of students of grade 18 is obviously higher than that of students of grade 17. This also shows that the teaching reform has made obvious progress. In view of the problems still existing in the teaching of activity design, we will further strengthen the research, strive to improve the teaching, and better promote the development of students' ability and accomplishment of activity design.

\section{References}

[1] Menaxin, "Problems and solutions of preschool education teaching method curriculum in Higher Vocational Colleges," Curriculum Textbook, Teaching method, vol. 35, no. 06, pp. 116-121, 2015.

[2] H. Yu, Y.Q. Zhang, H.L. Wang, "A brief discussion on the relationship between theory teaching and practice teaching," 5 Laboratory Science, vol. 2006, no. 4, pp.125-126.

[3] Y.H. Du, "Construction and implementation of practice teaching system for pre-school education specialty," 1 Courses. Teaching materials, Teaching method, vol. 33, no. 02, pp. 92-96, 2013.

[4] L. Yang, Y.Q. He, L.H. Zhai, “Construction and implementation of the practical teaching system of "three scenes, three levels and four collections" in Preschool Education Specialty," China Vocational and Technical Education, vol. 2018, no. 32, pp. 33-37+49.

[5] X.Y. Chen, "A study on the integration of teaching methods and courses in pre-school education with achievement-oriented," Occupation, vol. 2020, no. 05, pp. 60-61. 
[6] J.X. Liu, "Hierarchy of students'autonomous learning: interest, habituation, ritual and meaningand educational theory and practice," vol. 40, no. 35, pp. 7-10, 2020.

[7] X.Y. Xie, S.Y. Wu, "A study on strategies to improve the teaching design ability of normal students in preschool education," 1 Journal of Chengdu normal University, no. 02, pp. 70-76.

[8] L.X. Xiong, "Present situation and cultivation of independent learning ability of pre-school major students in higher vocational education — Taking hangzhou xx college as an example," Journal of Ningbo Institute of Education,vol. 22, no. 05, pp. 100-103.

[9] X.F. Li,"Research on the ability of collective teaching activity scheme design of Preschool Education Majors -- Taking the teaching practice of kindergarten activity integration and guidance in the experimental class of excellence program of $\mathrm{G}$ school as an example," Journal of Liupanshui Normal University, vol. 32, no. 06, pp. 88-92, 2020.

[10] H. Zhang, Y.Li, "Study on the strategy of school-enterprise cooperation in cultivating "double-qualified" teachers _ Taking pre-school education specialty in higher vocational education as an example," 1 China Adult Education, vol. 2014, no. 02, pp. 97-99.

[11] J.F.Cheng, "To strengthen practical teaching of applied undergraduate education, Research on Higher Education in China," vol. 2007, no. 7, pp. 54-55

[12] X.H. Wang, "Difficulties and Countermeasures for Teachers of Preschool Education Specialty in Colleges and Universities under the Concept ofPractice Education and Occupation," vol. 2015, no. 02, pp. 90-91.

[13] Q.H. Zhang,S.Z. Li, "Reconstructing the curriculum system of pre-school education specialty in vocational colleges from the perspective of educational phenomenology," Education and Occupation, vol. 2020, no. 23, pp. 104-107.

[14] G.P.Zhao,"On the relationship between practice teaching and theory teaching adult education in China," vol. 2010, no. 17, pp. 127-128.

[15] X.F. Li,"Study on the design ability of group teaching program for pre-school students — taking the teaching practice of"kindergarten activity integration and guidance" in the experimental class of $\mathrm{g}$ school excellence plan as an example," Journal of Liupanshui normal University.

[16] H.Q. Qi, "A trend of synthesizing teaching courses for pre-school education specialty, and educational research," vol. 2005, no. 09, pp. 93-96.

[17] Z.J.Li, D.F.Qiu, “Autonomous Learning: Teaching Conditions and Strategiesfor Students Global Education Outlook,” vol. 46, no. 01, pp. 47-57, 2017.

[18] R.X. Jin, "Research on the cultivation of college students' autonomous learning ability in the era of Internet +," Education and China Adult Education, no. 22, pp. 20-23, 2017.

[19] G.H.Liu,"A study on the transformation of learner-centered teaching strategies education and occupation," vol. 2013, no. 24, pp. 103-105. 